\title{
Quantitative intestinal digestion of nitrogen in sheep given formaldehyde-treated and untreated casein supplements
}

\author{
By J. C. MACRAE, M. J. ULYATT, P. D. PEARCE AND \\ JANE HENDTLASS \\ Applied Biochemistry Division, DSIR, Palmerston North, New Zealand \\ (Received 30 September 1970-Accepted 24 May 1971)
}

\begin{abstract}
I. In two experiments, sheep prepared with a rumen cannula and with re-entrant cannulas in the duodenum and ileum were continuously fed on diets of dried grass, dried grass plus formalin-treated casein, or dried grass plus untreated casein. Paper impregnated with chromic oxide was given once daily via the rumen fistula.

2. In ten $24 \mathrm{~h}$ collections of digesta entering the duodenum and eleven $24 \mathrm{~h}$ collections of digesta reaching the ileum of sheep given dried grass, there were highly significant correlations between the $24 \mathrm{~h}$ flows of $\mathrm{Cr}$ marker and the corresponding flows of dry matter, organic matter, nitrogen, gross energy, hemicellulose and cellulose $(P<0.01)$ at both sites.

3. Daily amounts of non-ammonia $\mathrm{N}$ and of individual amino acids entering and leaving the small intestine and of total $\mathrm{N}$ excreted in faeces and urine are given.

4. Net retention of supplementary $N$ was $36 \%$ when the supplement was administered as formalin-treated casein, but only $17 \%$ when it was administered as untreated casein.

5. Formalin treatment of casein significantly increased the daily amounts of non-ammonia $\mathrm{N}$ entering the small intestine $(P<\mathrm{O} \cdot \mathrm{OI})$ and the amounts of non-ammonia $\mathrm{N}$ apparently absorbed therein $(P<0.05)$.

6. Apparent absorption of amino acids from the small intestine was significantly greater $(P<0.05)$ with treated casein than with untreated casein. There were relative increases in the small amounts of several free amino acids measured, including taurine, in the ileal digesta of sheep receiving the treated casein supplement.
\end{abstract}

Nitrogen digestion and metabolism in the ruminant is at its most efficient when low- $\mathrm{N}$ diets are being consumed. Microbial degradation of ingested protein, within the rumen, can cause serious wastage of $\mathrm{N}$ when ruminants are given high-protein diets. Postruminal administration of protein and amino acids gives better utilization of the $\mathrm{N}$ than when the same $\mathrm{N}$ source is offered in the $\operatorname{diet}$ (Chalmers, Cuthbertson \& Synge, 1954; Reis \& Schinckel, I961, I963, 1964; Reis, I969).

A method which has been developed to overcome rumen degradation of dietary protein supplements is to treat them with formaldehyde. The formaldehyde forms acid-reversible cross-linkages with amino and amide groups, rendering the protein insoluble at the $\mathrm{pH}$ of the rumen $\left(5^{\cdot} 5^{-6 \cdot 5}\right)$. However, this protein is subsequently made available to the host by destruction of the linkages in the abomasum ( $\mathrm{pH} \mathrm{2-3)}$ and digestion in the small intestine (Ferguson, Hemsley \& Reis, 1967). Using this protein, Ferguson et al. ( $\mathrm{r}^{6} 67$ ) obtained substantial increases in wool growth when it was given as a supplement to roughage-fed sheep. Such treated casein was recently reported to have a nutritional value similar to casein administered per abomasum (Reis \& Tunks, I969); both produced an increased rate of wool growth of $62 \%$ over the basal level.

No quantitative studies have been reported on the site(s) of digestion of the supplement within the digestive tract. The present investigation was therefore designed to 
measure the disappearances of $\mathrm{N}$ and amino acids from the different regions of the alimentary tract of sheep given dietary supplements of treated casein. A preliminary report of this work has been given (MacRae, 1970).

In this study mean $24 \mathrm{~h}$ flows of digesta at the proximal duodenum and terminal ileum were estimated using chromic oxide $\left(\mathrm{Cr}_{2} \mathrm{O}_{3}\right)$ as a marker for correcting observed flows to average $24 \mathrm{~h}$ values (MacRae \& Armstrong, I969a). In the first part of the study opportunity was taken to evaluate the reproducibility of estimates derived by this technique.

\section{EXPERIMENTAL}

Sheep. Romney Marsh sheep, castrated males I-2 years old, weighing 40-45 kg, were used. Each sheep was prepared with a rumen cannula and with re-entrant cannulas in the proximal duodenum and in the terminal ileum (Brown, Armstrong \& MacRae, 1968). They were housed in metabolism crates under continuous artificial

\section{Table I. Plan of the experiment}

(Except where indicated, each sheep was equipped with a rumen cannula and with re-entrant cannulas in the proximal duodenum and terminal ileum; values in parentheses are the numbers of separate 24 h collections made from each sheep, if greater than 1 )

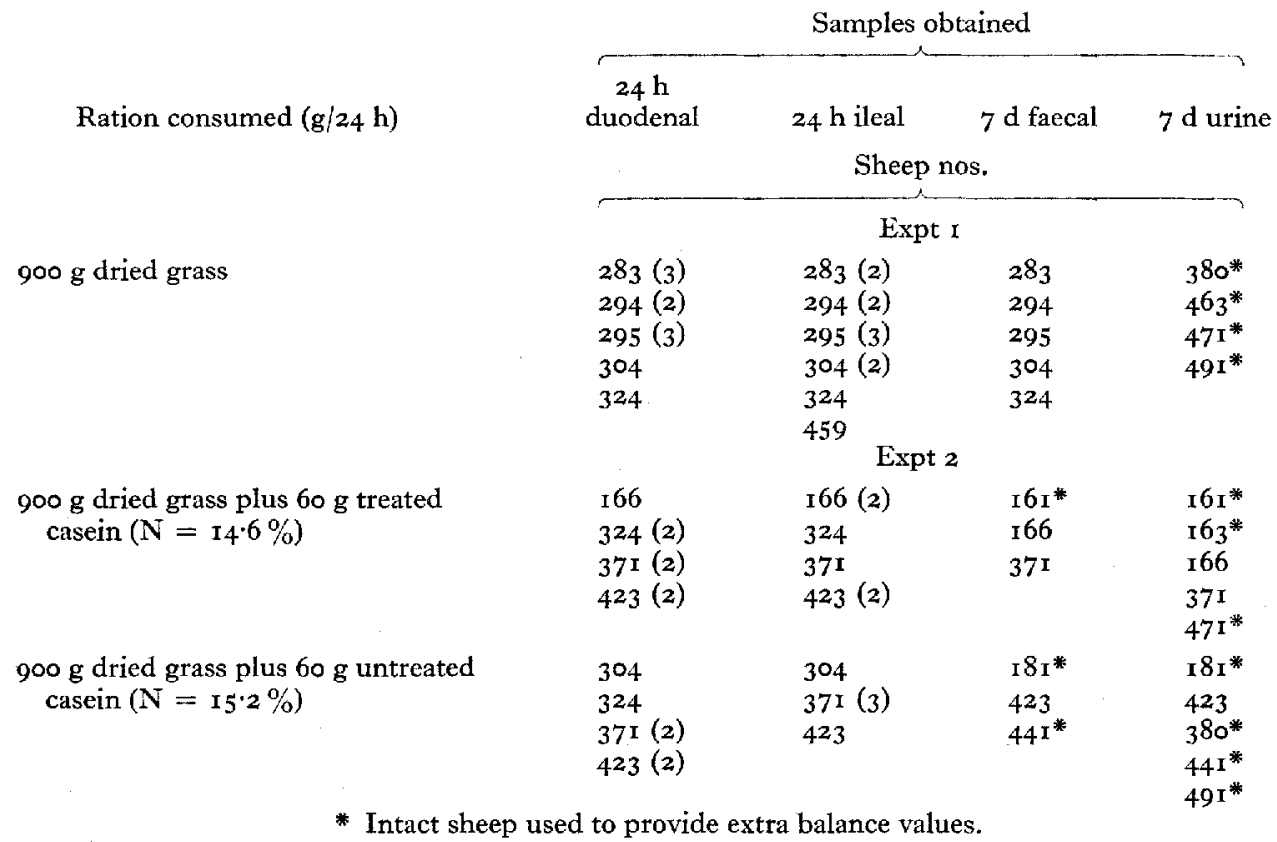

light and temperature $\left(\mathrm{I}_{5}-\mathrm{I} 8^{\circ}\right)$, had free access to water at all times, and received their rations from continuous-belt feeders, of the type previously described by Sutherland, Gupta, Reid \& Murray ( I964) and Ulyatt (1967).

Experimental design. Two experiments were conducted. In Expt $\mathrm{I}$ the sheep were given a basal diet of $900 \mathrm{~g}$ chopped dried grass ( $777 \mathrm{~g}$ dry matter (DM)). On a DM basis, this grass contained $\mathrm{N} \mathrm{2.6 \%}$, hot-water soluble carbohydrate (100 for $5 \mathrm{~min}$ ) 
$22 \cdot 3 \%$, cellulose $20 \cdot 6 \%$, hemicellulose $12.3 \%$, ash $8 \cdot \mathrm{r} \%$, gross energy $4.5 \mathrm{kcal} / \mathrm{g}$, and the apparent digestibility of its DM was $74.4 \%$. In Expt 2 certain of these sheep plus replacement animals were given the same basal diet supplemented with either acid-precipitated milk casein, or the same casein after treatment with formalin (both supplements were supplied by the New Zealand Dairy Research Institute, Palmerston North). Details are given in Table I. In Expt 2 the sheep were divided into two groups. In the first part of the experiment one group received treated casein and the other group received untreated casein; in the second part the diets were reversed. Additional balance results were obtained using intact sheep.

Marker. Shredded paper impregnated with chromic oxide $\left(\mathrm{Cr}_{2} \mathrm{O}_{3}\right)$ (Corbett, Greenhalgh, McDonald \& Florence, I960) was administered to all sheep. One pellet containing $6 \mathrm{~g}$ of $\mathrm{Cr}_{2} \mathrm{O}_{3}$-paper was placed in the rumen via the fistula at 09.00 hours daily, for a minimum period of $2 \mathrm{I} d$ before the start of each experiment.

Collection of samples. All food samples were obtained during the preparation of the rations.

During the preliminary $20 \mathrm{~d}$ study of faecal excretion of $\mathrm{Cr}$ marker, faeces were weighed daily, DM was determined and daily samples from each sheep were stored separately at $-20^{\circ}$ for subsequent analysis.

During Expts $\mathrm{I}$ and 2 collections of faeces and urine were made for $7 \mathrm{~d}$ periods before the $24 \mathrm{~h}$ intestinal collections. Urine was collected daily in $50 \mathrm{ml}$ of $30 \%$ $\mathrm{H}_{2} \mathrm{SO}_{4}$. Samples from total daily urine and faeces collections were kept at $-20^{\circ}$ before $7 \mathrm{~d}$ cumulative samples for each sheep were prepared by bulking in proportion to the weight excreted. The urine samples were stored at $-20^{\circ}$ for subsequent analysis whilst the faecal samples were freeze-dried and ground to pass the $\mathrm{I} \mathrm{mm}$ sieve of a Casella mill.

The procedures used for continuous $24 \mathrm{~h}$ collections of digesta from the duodenum and ileum were similar to those used by MacRae \& Armstrong (r969a). During duodenal collections the cannulas were disconnected and digesta leaving the proximal cannula were collected for consecutive $2 \mathrm{~h}$ periods. At the end of each $2 \mathrm{~h}$ period the digesta were weighed and homogenized and a sample ( $100-\mathrm{r} 50 \mathrm{~g}$ ) was stored at $-20^{\circ}$ for subsequent analysis. Smaller duplicate samples (10-20 g) were also taken from each $2 \mathrm{~h}$ collection for DM determination. The remaining digesta were then made up to their original weight with duodenal contents collected from a 'donor' animal given the same ration (Harris \& Phillipson, 1962) and, after warming to $40^{\circ}$, were slowly re-introduced into the small intestine via the distal cannula over the following $2 \mathrm{~h}$ period while the next $2 \mathrm{~h}$ samples were being collected. A similar procedure was adopted for the $24 \mathrm{~h}$ collections at the terminal ileum except that, owing to reduced flow at this point, samples were collected during periods of $3 \mathrm{~h}$ or longer. After the individual $2 \mathrm{~h}$ and $3 \mathrm{~h}$ samples had been freeze-dried and ground to pass the $\mathrm{I} \mathrm{mm}$ sieve of a Casella mill, cumulative samples of duodenal and ileal contents, representative of the $24 \mathrm{~h}$ flow, were prepared by bulking in proportion to the dry weight excreted.

Analyses. Moisture in all freeze-dried samples used for analysis was determined by drying at $105^{\circ}$ for $24 \mathrm{~h}$. Organic matter (OM) was determined by ashing samples at $55^{\circ}$ for $3 \mathrm{~h}$, gross energy with an adiabatic bomb calorimeter and hemicellulose and 
cellulose by the method of Bailey ( 1964$)$. Cr was determined by the atomic absorption method of Williams, David \& Iismaa ( 1962 ). Total $\mathrm{N}$ was determined in the freezedried samples and urine samples by a micro-Kjeldahl method. Levels of non-ammonia $\mathrm{N}$ in duodenal and ileal digesta were determined as the difference between amounts of total $\mathrm{N}$ and ammonia $\mathrm{N}$ in the freeze-dried samples. Ammonia $\mathrm{N}$ in the dried samples was extracted with boiling $80 \%$ ethanol and taken up in water before being measured by the method of Conway ( 1957 ).

The amino acid compositions of a representative selection of the freeze-dried samples were determined, after hydrolysis with excess $6 \mathrm{M}-\mathrm{HCl}$ at $110^{\circ}$ for $24 \mathrm{~h}$ in sealed tubes, using a Beckman Spinco $\mathbf{2} 20 \mathrm{C}$ automatic amino acid analyser. Free amino acids were extracted with a mixture of chloroform-methanol- $\mathrm{H}_{2} \mathrm{O}$ and passed through an ultra filtration unit before being measured on the amino acid analyser (Peterson, Hendtlass, MacRae \& Pearce, I97r).

\section{RESULTS}

\section{Evaluation of the 24 continuous sampling technique}

Faecal recovery of $\mathrm{Cr}$ marker. The amounts of $\mathrm{Cr}$ excreted daily in the faeces of seven sheep were recorded during a preliminary $20 \mathrm{~d}$ experiment, to obtain estimates of the recovery of marker and the variability of daily excretion. The values are given in Table 2. The mean faecal recoveries over the $20 \mathrm{~d}$ period were similar for all sheep and none differed significantly from the amount of $\mathrm{Cr}$ administered ( $\mathrm{r} \mathrm{I}_{3} \mathrm{mg} / 24 \mathrm{~h}$ ). However, the variation between days for each sheep was considerable, the average coefficient of variation being $17.5 \%$ per animal. In all subsequent work reported in this paper the average daily faecal excretion ( $1163 \mathrm{mg}$ ) has been taken as the quantity of $\mathrm{Cr}$ flowing through the digestive tract daily.

Table 2. Mean daily faecal recoveries of chromium in sheep given $1183 \mathrm{mg} / \mathrm{d}$ of $\mathrm{Cr}$ as $\mathrm{Cr}_{2} \mathrm{O}_{3}$ - impregnated paper via the rumen fistula over a 20 d experimental period

\begin{tabular}{|c|c|c|}
\hline Sheep no. & $\begin{array}{l}\text { Cr recovery } \\
(\mathrm{mg} / 24 \mathrm{~h})\end{array}$ & $\mathrm{SE}$ of a mean \\
\hline 283 & II 59 & \\
\hline $29 x$ & $\operatorname{II} 78$ & \\
\hline 294 & I 56 & \\
\hline 295 & I I 90 & 45 \\
\hline 300 & II 25 & \\
\hline 304 & 1177 & \\
\hline 324 & 1160 & \\
\hline Mean & $116_{3}$ & 17 \\
\hline
\end{tabular}

The use of $C r$ to correct observed $24 h$ flow values to mean $24 h$ values. If observed flows of $\mathrm{Cr}$ through the duodenal and ileal cannulas can be used to reflect flows of digesta constituents at these points, then regression analyses of the observed flows of $\mathrm{Cr}$ against the corresponding observed flows of constituent taken over a number of $24 \mathrm{~h}$ collections on a standard diet should be linear, with correlation coefficients approaching unity. In Expt I, ten separate $24 \mathrm{~h}$ duodenal collections were made from 
five sheep and eleven separate $24 \mathrm{~h}$ ileal collections were made from six sheep (see Table $\mathrm{x}$ ). Regression equations and correlation coefficients calculated for the relationship of duodenal and ileal flows of $\mathrm{Cr}$ against corresponding flows of DM, OM, N, gross energy, hemicellulose and cellulose are given in Table 3 . For all constituents the correlation coefficients were highly significant $(P<0 \cdot 01)$, which suggests that it is valid to correct all flows of constituents on the basis of $\mathrm{Cr}$ recovery when using the present continuous $24 \mathrm{~h}$ collection technique.

Table 3. Relationships of the observed 24 h flows of dry matter, organic matter, nitrogen, cellulose, hemicellulose and gross energy to the corresponding observed flows of chromium $(\mathrm{mg} / 24 \mathrm{~h})$ at the duodenum (ten separate collections from five sheep) and ileum (eleven separate collections from six sheep) of sheep given $900 \mathrm{~g}$ dried grass

Regression equation

Duodenum

$\begin{array}{ll}\text { Dry matter }(\mathrm{g} / 24 \mathrm{~h}) & =5.6+(0.38 \pm 0.043) \mathrm{Cr} \\ \text { Organic matter }(\mathrm{g} / 24 \mathrm{~h}) & =\mathrm{I} \cdot 9+(0.30 \pm 0.032) \mathrm{Cr} \\ \text { Nitrogen }(\mathrm{g} / 24 \mathrm{~h}) & =0.0 \mathrm{I}+(0.019 \pm 0.0035) \mathrm{Cr} \\ \text { Cellulose }(\mathrm{g} / 24 \mathrm{~h}) & =-2.2+(0.028 \pm 0.0027) \mathrm{Cr} \\ \text { Hemicellulose }(\mathrm{g} / 24 \mathrm{~h}) & =-7.6+(0.033 \pm 0.0048) \mathrm{Cr} \\ \text { Gross energy }(\mathrm{kcal} / 24 \mathrm{~h})= & -36.5+(\mathrm{I} .64 \pm 0.167) \mathrm{Cr}\end{array}$

Ileum
Correlation coefficient

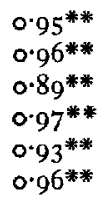

$0.93^{* *}$
$0.94^{* *}$
$0.87^{* *}$
$0.95^{* *}$
$0.97^{* *}$
$0.92 * *$ ** $P<$ o.or.

\section{Digestion of total $N$}

The quantities of $\mathrm{N}$ in the food, entering and leaving the small intestine, and in the faeces and urine of sheep given the three diets of dried grass, dried grass plus treated casein and dried grass plus untreated casein are given in Table 4.

Absorption of ammonia within the small intestine is not considered nutritionally important relative to absorption of other nitrogenous constituents. Duodenal samples contained varying amounts of ammonia $\mathrm{N}$, the greatest amounts being present in digesta from sheep given untreated casein supplements. For this reason quantities of non-ammonia $\mathrm{N}$ present in duodenal and ileal samples were measured and are also given in Table 4. It will be noted that there was negligible ammonia $\mathrm{N}$ in the freezedried ileal samples.

Daily amounts of non-ammonia $\mathrm{N}$ reaching the duodenum of the sheep receiving the dried grass $(2 \mathrm{r} \cdot 4 \mathrm{~g})$ and the treated casein $(30 . \mathrm{g})$ diets were similar to amounts of $\mathrm{N}$ consumed ( $20^{\circ} 6 \mathrm{~g}$ and $29^{\circ} 4 \mathrm{~g}$ respectively). However, the amount of non-ammonia $\mathrm{N}$ reaching the duodenum of sheep receiving untreated casein $(26.3 \mathrm{~g})$ was less than the $\mathrm{N}$ consumed $\left(29^{\circ} 7 \mathrm{~g}\right)$. Calculation on a within-animal basis showed that apparent absorption of non-ammonia $\mathrm{N}$ from the small intestine, measured as the difference 
between duodenal and ileal non-ammonia $\mathrm{N}$ levels, was significantly greater $(P<0.05)$ for sheep receiving the treated casein diet $\left(19^{\cdot 8} \pm \mathrm{r} \cdot 2 \mathrm{~g} / 24 \mathrm{~h}\right)$ than for those receiving the untreated casein diet $(\mathrm{I} 6.6 \pm 0.2 \mathrm{~g} / 24 \mathrm{~h})$, even though the latter contained a higher amount of $\mathrm{N}$. Both these apparent absorptions were significantly greater $(P<0.0 \mathrm{r})$ than found in sheep receiving the dried-grass diet $\left(13^{\circ} 0 \pm 0.4 \mathrm{~g} / 24 \mathrm{~h}\right)$.

Table 4. Mean quantities with their standard errors $(g / 24 h)$ of nitrogen present in the food, entering and leaving the small intestine, and in faeces and urine of sheep given dried grass, or dried grass plus treated or untreated casein

(Values for digesta at the duodenum and ileum have been adjusted for $100 \%$ recovery of chromic oxide; for sheep used see Table t)

$N$ in food

$\mathrm{N}$ at duodenum

Non-ammonia $N$ at duodenum

$\mathrm{N}$ at ilcum

Non-ammonia $\mathrm{N}$ at ileum

$N$ in faeces

$\mathrm{N}$ in urine

Digested N*

Retained N*

\begin{tabular}{|c|c|c|}
\hline $900 \mathrm{~g}$ dried grass & $\begin{array}{l}900 \mathrm{~g} \text { dried grass } \\
\text { plus } 6 \circ \mathrm{g} \text { treated } \\
\text { casein }\end{array}$ & $\begin{array}{c}900 \mathrm{~g} \text { dried grass } \\
\text { plus } 60 \mathrm{~g} \text { untreated } \\
\text { casein }\end{array}$ \\
\hline $20 \cdot 6$ & $29 \cdot 4$ & $29 \cdot 7$ \\
\hline $23 \cdot x \pm 0.6$ & $32 \cdot 0 \pm 0.8$ & $29.4 \pm 0.5$ \\
\hline $21 \cdot 4 \pm 0.6$ & $30.1 \pm 0.8$ & $26 \cdot 3=0.4$ \\
\hline $7 \cdot 8 \pm 0.4$ & $10.8 \pm 0.5$ & $10.0 \pm 0.4$ \\
\hline $7 \cdot 7 \pm 0 \cdot 4$ & $10.6 \pm 0.5$ & $9.9 \pm 0.4$ \\
\hline $6 \cdot 3 \pm 0 \cdot 4$ & $7 \cdot 3 \pm 0 \cdot 1$ & $6 \cdot 9 \pm 0 \cdot 3$ \\
\hline $8 \cdot 6 \pm 0.6$ & $13.3 \pm 0.8$ & I $5.5 \pm 0.8$ \\
\hline $14.3(69.4 \%)$ & $22 \cdot 1(75 \cdot 2 \%)$ & $22.8(76.8 \%)$ \\
\hline $5 \cdot 7(27 \cdot 7 \%)$ & $8.8(29.9 \%)$ & $7 \cdot 3(24 \cdot 6 \%)$ \\
\hline
\end{tabular}

* Values in parentheses represent \% of $\mathrm{N}$ intake.

Table 5. Mean values with their standard errors for non-ammonia nitrogen entering the small intestine and for $N$ excreted in the urine of sheep given dried grass or dried grass plus untreated casein once daily or by continuous feeder

(Values for digesta at the duodenum have bcen adjusted for $100 \%$ recovery of chromic oxide)

\begin{tabular}{|c|c|c|c|c|}
\hline & \multicolumn{2}{|c|}{$900 \mathrm{~g}$ dried grass } & \multicolumn{2}{|c|}{$\begin{array}{c}900 \mathrm{~g} \text { dried grass plus } 60 \mathrm{~g} \\
\text { untreated casein }\end{array}$} \\
\hline & $\begin{array}{l}\text { Feeding once } \\
\text { daily }\end{array}$ & $\begin{array}{l}\text { Continuous } \\
\text { feeding }\end{array}$ & $\begin{array}{l}\text { Feeding once } \\
\text { daily }\end{array}$ & $\begin{array}{l}\text { Continuous } \\
\text { feeding }\end{array}$ \\
\hline $\begin{array}{l}\text { Non-ammonia } N \text { at duodenum } \\
(g / 24 h)^{*}\end{array}$ & $22 \cdot 1 \pm 0 \cdot 4(6)$ & $2 \mathrm{r} \cdot 4 \pm 0.6(\mathrm{IO})$ & $26 \cdot 9 \pm 0 \cdot 9(6)$ & $26 \cdot 3 \pm 0.5(6)$ \\
\hline $\mathrm{N}$ in urine $(\mathrm{g} / 24 \mathrm{~h})^{*}$ & $9.7 \pm 0.8(3)$ & $8 \cdot 6 \pm 0.6(4)$ & $13 \cdot 5 \pm 1 \cdot 2(3)$ & $15.4 \pm 0.8(5)$ \\
\hline
\end{tabular}

Apparent absorption of $\mathrm{N}$ beyond the ileum, measured as the difference between the ileal $\mathrm{N}$ levels and the faecal $\mathrm{N}$ levels measured in the balance sheep, were considerably greater in sheep given treated casein $(3.5 \mathrm{~g} / 24 \mathrm{~h})$ and untreated casein $\left(3^{\circ} \mathrm{I} / 24 \mathrm{~h}\right)$ diets than in those given the dried-grass diet $(\mathrm{I} \cdot 5 \mathrm{~g} / 24 \mathrm{~h})$.

Daily amounts of $\mathrm{N}$ in the urine of sheep given treated casein and given untreated casein were significantly higher $(P<0.01$ and $P<0.001$ respectively) than in sheep given the dried-grass diet. As a result, net retention of $\mathrm{N}$ with the untreated and treated casein diets increased by $\mathrm{I} \cdot 6$ and $3 \cdot \mathrm{r} \mathrm{g} / 24 \mathrm{~h}$ respectively over that retained with the dried grass, though apparent absorption of $\mathrm{N}$ (food $\mathrm{N}$ minus faecal $\mathrm{N}$ ) increased by 8.5 and $7.8 \mathrm{~g} / 24 \mathrm{~h}$ respectively. 
The values presented in Table 4 were obtained for sheep that received their rations from continuous-belt feeders. To determine whether these results would be different under different feeding regimens, values for duodenal non-ammonia $\mathrm{N}$ and urinary $\mathrm{N}$ were obtained for animals given diets of dried grass and of dried grass plus untreated casein once daily at 09.00 hours. From the results, given in Table 5, it can be seen that there were no significant differences in the quantities of non-ammonia $\mathrm{N}$ reaching the duodenum or in $\mathrm{N}$ excreted in the urine under the two extremes of feeding procedure. The time taken for sheep to consume their rations once daily varied considerably, but all sheep consumed the diet within $6 \mathrm{~h}$ of being fed.

\section{Digestion of amino $N$}

Total amino acids. The quantities of individual amino acids present in the food, entering and leaving the small intestine and in the faeces of sheep given the three diets are shown in Table 6 . With dried grass and treated casein the amounts of isoleucine, lysine, methionine, threonine, valine, aspartic acid and tyrosine reaching the duodenum were almost as high as those consumed in the food. However, there was a net loss of all amino acids passing through the stomach in sheep given untreated casein.

There was considerable apparent absorption of all amino acids from the small intestine with each diet. Calculated on a within-sheep basis, apparent daily absorption of total amino acids from this region for the treated-casein diet ( I r $2 \cdot 7 \pm 5^{\cdot 2} \mathrm{~g}$ ) was significantly greater $(P<0.05)$ than that in sheep given the untreated-casein diet $\left(94^{6} 6 \pm 5^{\cdot} \mathrm{I} \mathrm{g}\right)$, which in turn, was significantly greater $(P<0.0 \mathrm{I})$ than that in sheep given dried grass $\left(74^{\circ} 9 \pm 2 \cdot 3 \mathrm{~g}\right)$.

Disappearances of amino acids from the large intestine were small with dried grass, but larger with untreated casein and largest with treated casein.

Analytical recoveries of the sixteen amino acids measured, as percentages of the protein (non-ammonia $\mathrm{N} \times 6.25$ ), in the food, duodenal, ileal and faecal samples are also given in Table 6 . With dried grass, $90 \%$ of the protein was accounted for as amino acids. With the casein supplements, $95 \%$ was so accounted for, hence the $92 \%$ recovery recorded in the dried-grass plus casein diets. This recovery dropped to $80-$ $83 \%$ for duodenal samples and further to $67-72 \%$ for ileal and faecal samples. Recoveries obtained in the diet and the duodenal samples compare well with the average analytical recoveries of $8 \mathrm{i} \pm 2$ and $96 \pm 2$ reported by Porter, Westgarth $\&$ Williams (I968) when nine laboratories analysed standard samples of cod liver and gelatin respectively.

Free amino acids. Amounts of free amino acids in all samples were very small and individual amino acids are not presented. However, there were increases in the amounts of several free amino acids leaving the small intestine when treated casein was given, which may suggest incomplete absorption of certain amino acids released from treated casein. For example, amounts of proline, alanine, valine, leucine and tyrosine in ileal samples increased from $8,22,20, \mathrm{I} 5$ and $8 \mathrm{mg} / 24 \mathrm{~h}$ respectively with the dried grass to $\mathrm{I}_{60}, \mathrm{II}_{4}, \mathrm{I}_{5} 2, \mathrm{I} 53$ and $67 \mathrm{mg} / 24 \mathrm{~h}$ respectively with treated casein.

There were also increases in the quantities of taurine leaving the small intestine with treated and untreated casein. Taurine does not occur in protein but, as a mam- 


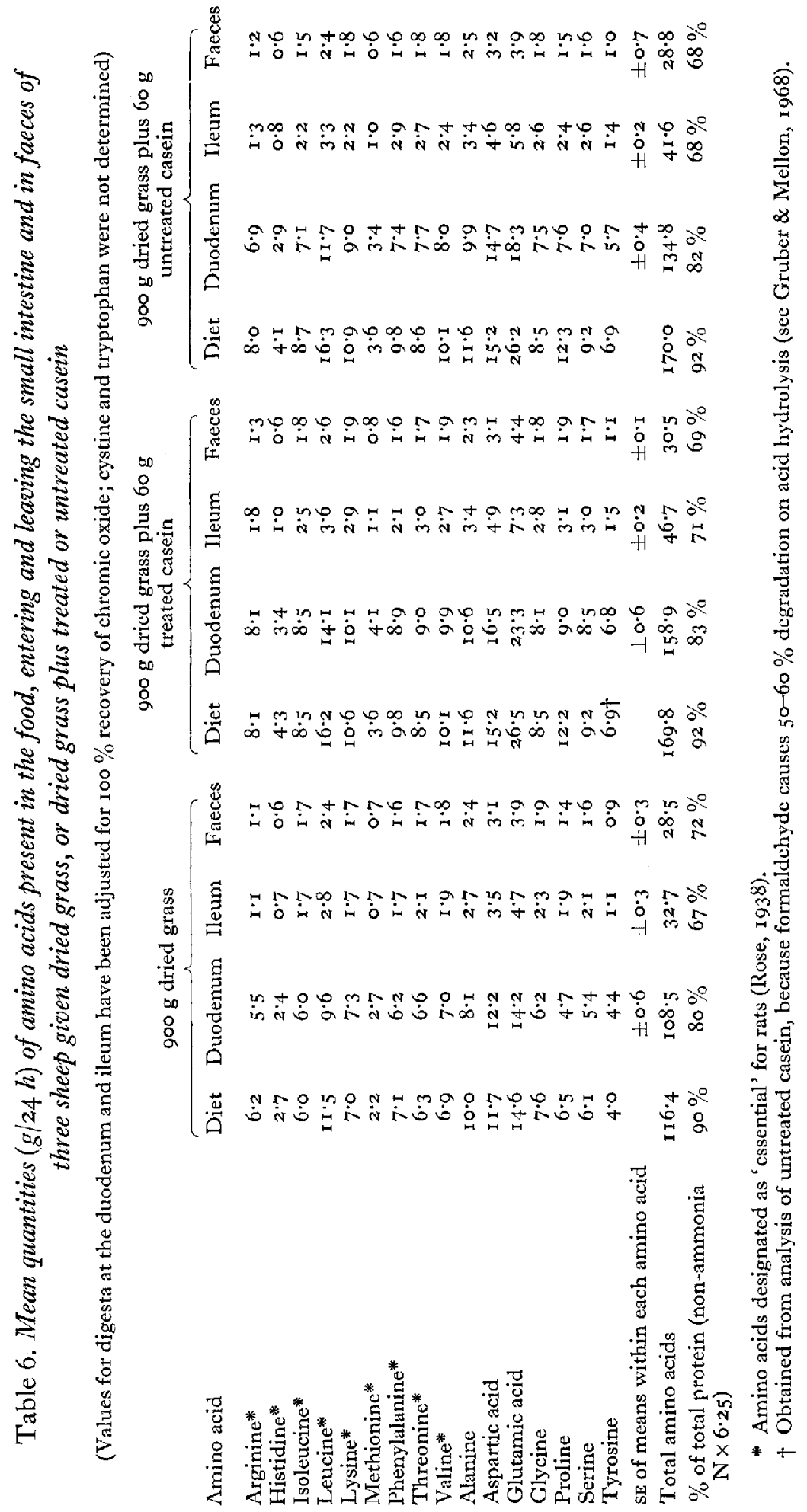


malian oxidation product of cystine, it is present in bile. Its increase in ileal digesta with treated casein (tenfold) and untreated casein (twofold) would suggest either increases in oxidative breakdown of cystine in the liver of sheep given the two supplements, or decreases in resorption of the taurine excreted in bile with the supplemented diets.

\section{DISCUSSION}

\section{Evaluation of the 're-entrant collection' technique}

Most studies using continuous intestinal sampling techniques with animals having re-entrant cannulas have used $\mathrm{Cr}_{2} \mathrm{O}_{3}$ as an indigestible marker to correct flows of digesta constituents to an average $24 \mathrm{~h}$ basis. However, $24 \mathrm{~h}$ collections of digesta from the duodenum or the ileum are frequently associated with low recoveries of $\mathrm{Cr}$ marker. In Expt I of the present study duodenal recoveries of Cr over the ten duodenal $24 \mathrm{~h}$ collections ranged from 56 to ror \% (average $82 \%$ ) of the daily faecal output of marker, and ileal recoveries over the eleven $24 \mathrm{~h}$ collections ranged from $3^{\mathrm{I}}$ to $104 \%$ (average $76 \%$ ). Similar results were obtained by Harris \& Phillipson ( 1962 ). Bruce, Goodall, Kay, Phillipson \& Vowles (I966), Topps, Kay \& Goodall (I968), MacRae \& Armstrong (I969a) and Nicholson \& Sutton (1969). During $7^{2} \mathrm{~h}$ ileal collections, Goodall \& Kay (1965) observed a reduced flow over the first $24 \mathrm{~h}$ which was compensated for during the subsequent $48 \mathrm{~h}$. Similarly van't Klooster, Rogers \& Sharma ( 1969 ) observed that recoveries of $\mathrm{Cr}_{2} \mathrm{O}_{3}$ during the first $24 \mathrm{~h}$ of a collection from the distal duodenum of two sheep were 91 and $90 \%$, while the mean recoverjes over a $3 \mathrm{~d}$ period were 99 and $98 \%$ respectively.

Because of this considerable variation in digesta flow and the tendency for the flow to be suppressed during collections it is necessary to correct observed $24 \mathrm{~h}$ flows to average $24 \mathrm{~h}$ values. However, the use of an indigestible marker such as $\mathrm{Cr}_{2} \mathrm{O}_{3}$ in such a correction necessitates the basic assumption that during a collection period the flow of marker reflects the flow of other digesta constituents. In previous studies of this nature the number of $24 \mathrm{~h}$ samples collected from animals on any one diet has usually been small, often as low as two, and the results available have been insufficient to test the assumption. However, the correlation and regression values presented in Table 3, which are based on the ten separate $24 \mathrm{~h}$ duodenal and eleven separate $24 \mathrm{~h}$ ileal collections of Expt $\mathrm{I}$, indicate that the assumption is in fact valid. The correlations show that the flow of $\mathrm{Cr}$ did reflect the flows of DM, OM, N, gross energy, hemicellulose and cellulose $(P<0.0 \mathrm{I})$.

An additional check on the technique can be made by comparing the average $24 \mathrm{~h}$ flows of constituents of the duodenal and ileal digesta which are not digested in the small intestine. In the present study the corrected $24 \mathrm{~h}$ flows of hemicellulose and cellulose into the small intestine were $28 \cdot 4 \pm \mathrm{I} \cdot 2 \mathrm{~g}$ and $29 \cdot 7 \pm 0 \cdot 6 \mathrm{~g}$ respectively. The amounts of the same constituents leaving the small intestine were $27 \cdot 8 \pm \mathbf{I} \cdot \mathrm{I} g$ and $3^{\circ} \cdot \mathrm{I} \pm \mathrm{I} \cdot 6 \mathrm{~g}$ respectively. Similar agreement between cellulose entering and leaving the small intestine was obtained by Bruce et al. (1966), Topps et al. (1968), MacRae \& Armstrong (1969b) and Thomson, Beever, Coehlo da Silva \& Armstrong (I969). 


\section{Digestion of nitrogenous constituents}

Quantities of non-ammonia $\mathrm{N}$ reaching the duodenum, relative to dietary $\mathrm{N}$ levels, were high in our experiments (Table 4) compared with reports on other high-N diets. Thus when Clarke, Ellinger \& Phillipson (1966) gave a diet of hay plus soya bean $(25 \mathrm{~g} \mathrm{~N} / 24 \mathrm{~h}$ ) only $70 \%$ reached the duodenum as non-ammonia N. Similarly, when Hogan \& Weston ( 1967 ) gave chopped and ground lucerne ( $3 \circ \mathrm{g} \mathrm{N} / 24 \mathrm{~h}$ ) only 77 and $79 \%$ respectively reached the duodenum as non-ammonia $\mathrm{N}$. It was suggested earlier (MacRae, 1970) that high values for non-ammonia $\mathrm{N}$ in the present study may have been caused by the continuous feeding system. Constant feeders spread the intake of the ration throughout the $24 \mathrm{~h}$ period and this might lead to a greater production of microbial protein from rumen ammonia. However, the results given in Table 5 invalidate this hypothesis, and it is now suggested that the explanation for the high duodenal flows of non-ammonia $\mathrm{N}$ is probably the very high content of soluble carbohydrate in the dried grass used in this work (hot-water soluble carbohydrate, $22 \cdot 3 \%$ ). This soluble carbohydrate provides a readily available source of energy for the synthesis of rumen microbial protein. The quantity of soluble carbohydrate consumed with the dried grass used in Expt I ( $173 \mathrm{~g} / 24 \mathrm{~h}$ ) was more than double the quantity $(74 \mathrm{~g} / 24 \mathrm{~h}$ ) consumed in the lucerne diets given by Hogan \& Weston (1967).

It has been claimed that the increases in live-weight gain and wool growth obtained when formalin-treated casein is given to sheep are due mainly to the fact that formalin protects the casein from degradation by rumen micro-organisms (Ferguson et al. 1967; Reis, I969; Reis \& Tunks, 1969). Although the present experiments were unable to determine directly whether formalin treatment afforded complete protection from in vivo rumen fermentation, the values given in Table 4 show that treatment did in fact significantly increase the daily amount of non-ammonia $\mathrm{N}$ entering the small intestine $(P<0.01)$ and the amount of non-ammonia $\mathrm{N}$ apparently absorbed therein $(P<0.05)$ over the corresponding observations with untreated casein.

Indeed it can be seen, from comparison of the duodenal flow values for the treatedcasein diet with those for the dried-grass diet, that the extra non-ammonia $N$ passing to the duodenum on the supplemented diet was very nearly the same amount as that given with the casein supplement. In contrast, increases in flow of non-ammonia $\mathrm{N}$ to the duodenum when untreated casein was given were equivalent to only some $50-55 \%$ of the extra amount supplied as the supplement. Similarly, when treated casein was given, the flow of most amino acids to the duodenum was increased over that observed with dried grass by an amount similar to that supplied in the supplement, but for all amino acids other than histidine, alanine and glycine, the additional flow of amino acids to the duodenum with untreated casein was much less than the extra dietary amino acids supplied by the casein supplement.

In experiments where a basal diet is given first alone and then with various supplements, the results would appear to lend themselves to many calculations concerning the digestion of the supplements. Thus in previous experiments calculations of the apparent availability of supplements of treated and untreated casein have been obtained from values of the differences in faecal $\mathrm{N}$ between the basal diet and the 
same diet supplemented with casein. Such values, reported by Reis \& Schinckel (196I), Blaxter \& Martin (1962), Ferguson et al. (1967) and Reis \& Tunks (1969) are in agreement with those similarly calculated for the treated casein $(89 \%)$ and untreated casein $(93 \%)$ given in our experiments. It might also appear that, using the observations of intestinal flow made in our experiments, the fate of the supplementary $N$ during its passage through the digestive tract could be followed. For example, from Table 2 it could be calculated that, of the $\mathrm{N}$ given as formalin-treated casein, $98 \%$ reached the duodenum as non-ammonia $\mathrm{N}, 65 \%$ was apparently absorbed from the small intestine and $24 \%$ disappeared in the large intestine. However, there is no guarantee that the pattern of digestion of dried grass would remain the same on addition of the supplement, and therefore it would be unwise to place too much value on such calculations.

In this study, differences between amounts of non-ammonia $\mathrm{N}$ and amino acids entering and leaving the small intestine have been termed apparent absorption. True absorption values cannot be given, because the measurements are merely balances between absorption and secretion. It is likely that endogenous secretions into the intestine are considerable. For example, Campbell, Cuthbertson, Mackie, McFarlane, Phillipson \& Sudsaneh ( $196 \mathrm{r}$ ) used ${ }^{131}$ I-labelled albumin to calculate that a maximum of $8 \mathrm{~g}$ plasma albumin $/ 24 \mathrm{~h}$ enters the small intestine in sheep. In man it has been estimated that pancreatic secretions can provide $8 \mathrm{~g}$ protein $/ 24 \mathrm{~h}$ and daily mucosal desquamation can add $50 \mathrm{~g}$ protein into the gut (Munro, I966). In sheep, Kay (I969) measured secretions of $\mathrm{I} \cdot 5 \mathrm{~g} \mathrm{~N} / 24 \mathrm{~h}$ into two loops of jejunum and one loop of ileum (total length $18.5 \mathrm{~m}$ ) and suggested that bile, pancreatic juices and duodenal secretions could contribute another $2 \mathrm{~g} \mathrm{~N} / 24 \mathrm{~h}$. On the other hand, there is likely to be considerable metabolism of amino acids during active absorption processes (Texter, Chou, Laureta \& Vantrappen, 1968).

Even though true absorption values cannot be given, it would appear that increases in apparent absorption of amino acids from the small intestine demonstrated in this work could probably account for increases in wool growth and live-weight gain observed in other experiments. However, it must be remembered that, of the extra $3^{6} \mathrm{~g}$ of amino acids apparently absorbed from the small intestine when treated casein was given (see Table 6), only $19 \mathrm{~g}$ of protein $(\mathrm{N} \times 6.25)$ were retained by the sheep. It may well be that variations in production responses observed when treated casein is given are functions more of the utilization of the extra metabolites than of the digestion of the supplement. Indeed it is probable that utilization of extra amino $\mathrm{N}$ would be directly related to the nutritional status of the animal.

The authors wish to acknowledge the skilled assistance of Dr N. D. Grace and Messrs S. Pickmere, D. Shelton, P. Vlieg and A. King and the DSIR Applied Biochemistry Division Analytical group. The help given by Dr C. S. W. Reid in the initial establishment of re-entrant cannulas, and by Mr R. Fletcher, DSIR Applied Mathematics Division, in statistical analyses, is also gratefully acknowledged. 


\section{REFERENCES}

Bailey, R. W. (1964). N.Z. $尹$ ll agric. Res. $7,496$.

Blaxter, K. L. \& Martin, A. K. (I962). Br. F. Nutr. 16, 397.

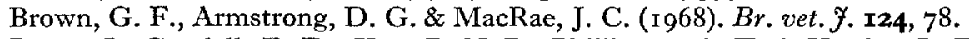

Bruce, J., Goodall, E. D., Kay, R. N. B., Phillipson, A. T. \& Vowles, L. E. (I966). Proc. R. Soc. B г66, 46.

Campbell, R. M., Cuthbertson, D. P., Mackie, W., McFarlane, A. S., Phillipson, A. T. \& Sudsaneh, S. (196r). F. Physiol., Lond. $\mathbf{5}_{58}$, I 13 .

Chalmers, M. I., Cuthbertson, D. P. \& Synge, R. L. M. (1954).F. agric. Sci., Camb. 44, 254.

Clarke, E. M. W., Ellinger, G. M. \& Phillipson, A. T. (r966). Proc. R. Soc. B 166, 63.

Conway, E. J. (1957). Micro-diffusion Analysis and Volumetric Error $4^{\text {th }}$ ed. London: Lockwood.

Corbett, J. L., Greenhalgh, J. F. D., McDonald, I. \& Florence, E. (I960). Br. F. Nutr. I4, 289.

Ferguson, K. A., Hemsley, J. A. \& Reis, P. J. (I967). Aust. F. Sci. 30, 215.

Goodall, E. D. \& Kay, R. N. B. (1965). F. Physiol., Lond. 176, r2.

Gruber, H. A. \& Mellon, E. F. ( 1968), Analyt. Biochem. 26, I80.

Harris, L. E. \& Phillipson, A. T. (1962). Anim. Prod. 4, 97.

Hogan, J. P. \& Weston, R. H. (1967). Aust. F. agric. Res. 18, 803.

Kay, R. N. B. (1969). Proc. Nutr. Soc. 28, 140.

MacRae, J. C. (I970). Proc. N.Z. Soc. Anim. Prod. 30, 218.

MacRae, J. C. \& Aimstrong, D. G. (1969a). Br. F. Nutr. 23, I5.

MacRae, J. C. \& Armstrong, D. G. (1 969b). Br. F. Nutr. 23, 377.

Munro, H. N. (1966). In Postgraduate Gastroenterology (Proc. Conf. 1965) p. 58 [T. J. Thomson and I. E. Gillespie, editors]. London: Baillière, Tindall \& Cassell.

Nicholson, J. W. G. \& Sutton, J. D. (I969). Br. F. Nutr. 23, 585 .

Peterson, P. J., Hendtlass, J., MacRae, J. C. \& Pearce, P. D. (r971). F. Sci. Fd Agric. 22 (in the Press).

Porter, J. W. G., Westgarth, D. R. \& Williams, A. P. (I968). Br.F. Nutr. 22, 437.

Reis, P. J. (1969). Aust. F. biol. Sci. 22, 745.

Reis, P. J. \& Schinckel, P. G. (1961). Aust. F. agric. Res. 12, 335.

Reis, P. J. \& Schinckel, P. G. (1963). Aust. F. biol. Sci. 16, 21 8.

Reis, P. J. \& Schinckel, P. G. (1964). Aust. F. biol. Sci. 17, 532.

Reis, P. J. \& Tunks, D. A. (1969). Aust. F. agric. Res. 20, 775.

Rose, W. C. (1938). Physiol. Rev. 18, I09.

Sutherland, T. M., Gupta, B. N., Reid, R. S. \& Murray, M. G. (1964). Proc. int. Congr. Nutr. vi. Edinburgh, $196_{3}$, p. 579 .

Texter, E. C. Jx., Chou, C.-C., Laureta, H. C. \& Vantrappen, G. R. (Ig68). Physiology of the Gastrointestinal Tract Ch. 25. St Louis, Mo.: C. V. Mosby.

Thomson, D. J., Beever, D. E., Coehlo da Silva, J. F. \& Armstrong, D. G. (1969). Proc. Nutr. Soc. 28, 24 A.

Topps, J. H., Kay, R. N. B. \& Goodall, E. D. (1968). Br. F. Nutr. 22, 26 I.

Ulyatt, M. J. (1967). Proc. N.Z. Soc. Anim. Prod. 27, 18r.

van't Klooster, A. Th., Rogers, P. A. M. \& Sharma, H. R. (1969). Neth. F. agric. Sci. 17, 60.

Williams, C. H., David, D. J. \& Iismaa, O. (1962). F. agric. Sci., Camb. 59, 381. 